E3S Web of Conferences 1, 09005 (2013)

DOI: $10.1051 / \mathrm{e} 3$ sconf/20130109005

(c) Owned by the authors, published by EDP Sciences, 2013

\title{
Adsorptive stripping voltammetric determination of trace amounts of lead in environmental water samples with complicated matrix
}

\author{
M. Grabarczyk and A. Koper \\ Faculty of Chemistry, Maria Curie-Sklodowska University, M. C. Sklodowska sq. 3, 20-031 Lublin, Poland \\ mgrabarc@poczta.umcs.lublin.pl, anna.koper535@gmail.com
}

\begin{abstract}
A sensitive, simple and fast adsorptive stripping voltammetric procedure for trace determination of lead in environmental water samples has been developed. The method is based on adsorptive accumulation of the $\mathrm{Pb}$ (II)-cupferron complex onto a hanging mercury drop electrode, followed by the reduction of the adsorbed species by a voltammetric scan using differential pulse modulation. The interference from surface active substances was eliminated by adsorption of interferents onto an Amberlite XAD-16 resin. Optimum conditions for removing the surfactants by mixing the analysed sample with resin were evaluated. The accuracy of the method was tested by analyzing certified reference material (SPS-WW1 Waste Water).
\end{abstract}

Key words: $\mathrm{Pb}$ (II), Adsorptive stripping voltammetry, Surface active substances, Environmental waters

\section{Introduction}

The determination of heavy metals, such as lead in natural waters is of environmental concern due to their toxicity for living organisms [Abdel-Halim et al., 2003; Cheng $\mathrm{Z}$ and Foland 2005]. Lead is introduced into the environment from a variety of human activities such as the manufacture of batteries, metal products, paints, and ceramic glazes. Even small amounts of lead that enter the environment can result in its elevated concentrations and, consequently, in its accumulation [Mesquita et al., 2004]. Therefore, there is a need to develop simple and cheap procedures for monitoring of lead in the environment.

Various analytical procedures based on the use of different instrumental techniques have been developed for the determination of heavy metals. Among them voltammetric methods are known to show unique advantages: economic i.e. low initial and running costs, the ability to determine very low concentrations of metal and may generally be regarded as non-destructive detection methods. Considering this, it is not surprising that a lot of adsorptive voltammetric procedures for $\mathrm{Pb}(\mathrm{II})$ determination based on accumulation of complexes of lead at the working electrode have been developed. For this purpose various complexing agents are exploited. In all the other procedures it was ascertained that organic matter present in natural samples caused an interference so UV-digestion of samples had to be employed before $\mathrm{Pb}$ (II) determination [Arancibia et al., 2009; Ensafi et al., 2003; Ensafi et al., 2006].

Thus the main purpose of this work was a precise examination of the influence of different kinds of surfactants on the $\mathrm{Pb}$ (II) voltammetric signal and then elimination of these interferences by Amberlite XAD-16 resin. The possibility of adsorptive stripping voltammetric (AdSV) determination of $\mathrm{Pb}(\mathrm{II})$ in environmental water samples without need of $\mathrm{UV}$-digestion is described.

\section{Materials and Methods}

The measurements were made using an EA-9 electrochemical analyzer and a controlled growth static mercury drop electrode in the HMDE mode, both made by MTM-ANKO Cracow, Poland. A three electrode system consisting of an $\mathrm{Hg}$ drop working electrode, a $\mathrm{Pt}$ auxiliary electrode and an $\mathrm{Ag} / \mathrm{AgCl}$ reference electrode were used.

An aliquot of standard $\mathrm{Pb}(\mathrm{II})$ or an analysed sample solution was placed into a glass vial, next $2 \mathrm{~mL}$ of 1.0 mol L ${ }^{-1}$ acetate buffer $\mathrm{pH}=4.6$ was added, and the total volume of the test solution was finally made up to $10 \mathrm{~mL}$ with water, next $1 \mathrm{~g}$ of dry Amberlite XAD-16 resin was added. Then a small magnetic stirring bar was put into the vial and the solution was mixed by stirring for $5 \mathrm{~min}$ at room temperature. Within this time surfactants potentially present in the sample were removed by adsorption on resin. Next, after sedimentation of resin $5 \mathrm{~mL}$ of the solution was pipetted into the voltammetric cell and then $500 \mu \mathrm{L}$ of $1 \times 10^{-2} \mathrm{~mol} \mathrm{~L}^{-1}$ cupferron and $4.5 \mathrm{~mL}$ of water were added and deaeration for $5 \mathrm{~min}$. was performed. A mercury drop was formed, and the accumulation of the 
$\mathrm{Pb}$ (II)-cupferron complex was carried out at $-0.05 \mathrm{~V}$ for $30 \mathrm{~s}$ from the stirred solution. After the equilibration time of 5 $\mathrm{s}$, the differential pulse voltammogram was recorded, while the potential was scanned from $-0.05 \mathrm{~V}$ to $-0.65 \mathrm{~V}$, with the intensity of the obtained peak directly proportional to the concentration of $\mathrm{Pb}$ (II) in the sample. The scan rate and pulse height were $20 \mathrm{mV} \mathrm{s}^{-1}$ and -50 $\mathrm{mV}$, respectively.

\section{Results and Discussion}

The optimization of the procedure was mainly concentrated on selection of the optimum conditions for an elimination of the interference of organic matter by using Amberlite XAD-16 resin. To obtain optimal conditions of removing surface active substances by adsorption on Amberlite XAD-16 resin the effects of the $\mathrm{pH}$ of the acetate buffer, the amount of resin, the time of sample contact with resin were considered.

The $\mathrm{pH}$ of the acetate buffer was changed in the range from 3 to 6 and the measurements were performed from solutions containing $5 \times 10^{-8} \mathrm{~mol} \mathrm{~L}^{-1} \mathrm{~Pb}$ (II) both in the absence and presence of Triton X-100 at concentration $20 \mathrm{ppm}$. The results indicate that in the whole tested $\mathrm{pH}$ range the lead signal is practically the same both in the presence and absence of the surfactant, which suggests that the resin effectively removes the surfactant in the range of the $\mathrm{pH}$ from 3 to 6 . For further measurement, the $\mathrm{pH}=4.6$ was chosen as the most suitable compromise of efficiency of surfactant removing, sensitivity of lead signal and acetate buffer capacity.

The time of mixing the sample containing $5 \times 10^{-8}$ mol $\mathrm{L}^{-1} \mathrm{~Pb}(\mathrm{II})$ and different concentrations of Triton $\mathrm{X}-100$ in the range from 10 to $30 \mathrm{mg} \mathrm{L}^{-1}$ with XAD-16 resin was changed from 5 to $20 \mathrm{~min}$. In the whole range of Triton X-100 concentrations, the time of $5 \mathrm{~min}$ was sufficient to obtain a stable peak for $\mathrm{Pb}(\mathrm{II})$. Further lengthening of the resin and sample contact time did not maximise the efficiency of surface active substances removal.

In order to investigate the influence of amount of XAD-16 resin on the efficiency of surface active substances removal, experiments with different masses of resin in the range from 0.1 to $2 \mathrm{~g}$ and different concentrations of Triton X-100 in the range from 10 to 30 $\mathrm{mg} \mathrm{L}^{-1}$ added to the sample solutions were carried out. As can be seen, with the increase of the mass of the resin the efficiency of Triton X-100 removal also increases. The addition of $1 \mathrm{~g}$ XAD-16 resin to the $10 \mathrm{~mL}$ sample effectively removes surface active substances interferences even in the presence of $30 \mathrm{ppm}$ Triton $\mathrm{X}-100$. Taking into account these results $1 \mathrm{~g}$ of resin was chosen for further measurements. However, in the case of samples containing larger amounts of surface active substances the mass of the resin can be increased.

The effect of surfactants of different charge types, which can generally accompany lead in environmental samples, was studied under optimised conditions. Sodium dodecyl sulfate (SDS), cetyltrimethylammonium bromide (CTAB) and Triton $\mathrm{X}-100$ as the representative for anionic, cationic and nonionic types, respectively were chosen to test. It turned out that the presence of even 30 ppm of CTAB, SDS and Triton X-100 does not influence the peak current of $\mathrm{Pb}(\mathrm{II})$.

The calibration graph for $\mathrm{Pb}(\mathrm{II})$ for an accumulation time of $30 \mathrm{~s}$ was linear in the range from $3 \times 10^{-9}$ to $5 \times$ $10^{-7} \mathrm{~mol} \mathrm{~L}^{-1}$ with the linear correlation coefficient $\mathrm{r}=$ 0.997. The relative standard deviation from five determinations of $\mathrm{Pb}(\mathrm{II})$ at a concentration of $5 \times 10^{-9}$ mol L $\mathrm{L}^{-1}$ for an accumulation time $30 \mathrm{~s}$ was $3.3 \%$. The detection limit estimated from 3 times the standard deviation of low $\mathrm{Pb}(\mathrm{II})$ concentration and accumulation time $30 \mathrm{~s}$ was $7.1 \times 10^{-10} \mathrm{~mol} \mathrm{~L}^{-1}$.

The validation of the proposed method was tested by determining the content of lead in the certified reference material SPS-WW1 Waste Water (batch 111). This water sample was submitted to analysis without any pretreatment. The results of determination $(n=10)$ show that the certified value $\left(100.0 \pm 0.5 \mathrm{ng} \mathrm{mL}^{-1}\right)$ and found value $\left(97.1 \pm 0.4 \mathrm{ng} \mathrm{mL}^{-1}\right)$ correspond well. To verify if the proposed method of the organic matrix removal by means of Amberlite XAD-16 is correct the analyzed reference material was additionally spiked with $20 \mathrm{ppm}$ Triton X-100, 20 ppm SDS and 20 ppm CTAB simultaneously. The obtained result of $\mathrm{Pb}$ (II) quantification was $96.2 \pm 0.6 \mathrm{ng} \mathrm{\textrm {mL } ^ { - 1 }}$.

\section{Conclusion}

It has been concluded that the use of Amberlite XAD-16 resin for elimination of the negative influence of surfactants on adsorptive stripping voltammetric determination of lead is the right idea. The optimized procedure proposed in this work is simple, sensitive and first of all it potentially allows for lead determination in some environmental water samples without matrix removal or any sample pretreatment. The proposed method is suitable for determining lead in environmental waters with advantages such as simplicity of operation, low cost and no need for a higher purity matrix.

\section{References}

Abdel-Halim SH, Shehata AMA, El-Shahat MF. Removal of lead ions from industrial waste water by different types of natural materials. J Hazardous Materials 2003; 37:1678-1687.

Arancibia V, Nagles E, Cornejo S. Nanoporous membrane-based cell chip for the study of anti-cancer drug effect of retinoic acid with impedance spectroscopy. Talanta 2009; 80:184-194.

Cheng Z, Foland KA. Lead isotopes in tap water: implications for $\mathrm{Pb}$ sources within a municipal water supply system. Appl Geochem 2005; 20:353-365.

Ensafi AA, Khayamian T, Atabati M. Differential pulse cathodic stripping adsorption voltammetric determination of trace amounts of lead using factorial design for optimization Talanta 2003; 59:727-733.

Ensafi AA, Khayamian T, Benvidi A, Mirmomtaz E. Simultaneous determination of copper, lead and cadmium by cathodic adsorptive stripping voltammetry using artificial neural network. Anal 
Chim Acta 2006; 561:225-232.

Mesquita RBR, Fernandes SMV, Rangel AOSS. A flow system for the spectrophotometric determination of lead in different types of waters using ion-exchange for pre-concentration and elimination of interferences water by different types of natural materials. Talanta 2004; 62:395-401. 